\title{
Integrating a Work-Study Programme in an Entrepreneurship Course to Develop Leadership
}

\author{
Nathalie Lameta \\ Teacher in Economy and Management, Educational Director of the Professional License \\ Entrepreneurship, University Institute of Technology Corsica \\ UMR LISA 6234 - University of Corsica, BP 5220250 Corte
}

\section{Christophe Storaï}

Lecturer in Economics and Director of the University Apprenticeship Training Centre (CFA UNIV) Corsica, University Institute of Technology Corsica, UMR LISA 6234 - University of Corsica, BP 52 20250 Corte

Summary: Today, there are many Entrepreneurship course opportunities in higher education curricula (universities, management schools). They help gain the necessary skills to manage a company. Sandwich courses offer a training in real-life professional situation likely to develop leadership and thus respond positively to the underlying challenge of business creation/takeover entrepreneurial activities.

Context: Teaching leadership to future entrepreneurs is not simple since this field requires self in-depth thinking as well as reflection on our relationship with others. The major challenge is to create representative didactic transpositions of future situations in their professional lives within a classroom standard framework.

Challenges: One of the major objectives of entrepreneurship courses is to discuss with students the questions and challenges associated with team management, leadership and performance assessment and learn how to better manage collective situations. A successful team depends on the contribution of every team member and in particular a trusting environment to be built by the team leader. The leader's task is also to set objectives, remove barriers, make decisions and carry them out. Teachers often use case studies to illustrate best practices ${ }^{l}$. However, leadership is an action, '" a praxis is mostly gained through experience, others' experience first, and then our own experience." (Lapierre, 2006).

\section{METHOD}

Entrepreneurship is "the phenomenon associated with entrepreneurial activity, human action to be taken to generate value by creating or developing economic activities through the identification and exploitation of new products, processor market" OECD (2011). "Entrepreneurship" refers to the emergence of an organisation (process where individuals create an organisation) or to the identification or exploitation of a new opportunity. This translates into different modalities: business creation from scratch, business take over, creation of activity within existing companies, product development, innovation... Entrepreneurship also refers to entrepreneurial spirit (associated with the corporate culture) and entrepreneurship spirit (entrepreneurial culture in different situations: personal life, community life, entrepreneurship, Intrapreneurship...) $)^{2}$.

The entrepreneur skills can be gained during training courses. A growing number of courses in entrepreneurship are offered in higher education to develop entrepreneurial skills. An entrepreneur is also a leader, referred to as "entrepreneurial leadership ${ }^{31 "}$ : the entrepreneur has an ability to create change and innovation as well as a leader capacity to manage the change, in particular in changing, uncertain and difficult situations (Kotter, 1990).

\footnotetext{
${ }^{1}$ Gillet C. ,Reynet O. , Coadour D. , 2015.

${ }^{2}$ Openbook entrepreneurship.

${ }^{3}$ La Violette, 2011. 
Leadership is however seen by young people as one of the weakest qualities and they are not necessarily aware of the challenge posed by this 'quality' in the entrepreneurial process

Young people and their perception of entrepreneurial qualities

\begin{tabular}{|l|l|l|l|}
\hline Which of the following qualities, are the best two... & Your weakest quality \\
\hline Qualities & $\begin{array}{l}\text { The most important } \\
\text { ones to set up a project }\end{array}$ & Your strongest quality & $13 \%$ \\
\hline Determination & $34 \%$ & $26 \%$ & $\mathbf{4 8 \%}$ \\
\hline Self confident & $\mathbf{3 5 \%}$ & $17 \%$ & $\mathbf{1 0 \%}$ \\
\hline Believing in your project & $\mathbf{4 3 \%}$ & $13 \%$ & $8 \%$ \\
\hline Being resourceful & $22 \%$ & $\mathbf{4 2 \%}$ & $30 \%$ \\
\hline Creative & $13 \%$ & $21 \%$ & $11 \%$ \\
\hline Assuming your choices & $7 \%$ & $26 \%$ & $11 \%$ \\
\hline Team spirit & $13 \%$ & $\mathbf{3 1 \%}$ & $\mathbf{4 5 \%}$ \\
\hline Leadership & $4 \%$ & $5 \%$ & \\
\hline
\end{tabular}

Source: "Entrepreneurial Spirit: what are the youth aspirations? What support from the local branches? ", 2013.

Yet, once they enter into an entrepreneurial process, they realise it is a barrier.

Barriers to young entrepreneurs are summarised in the following diagram.

Financial means
Experience
Market confidence
Innovating idea
Leadership
Independence
Work ability
Support from others
No Opinion

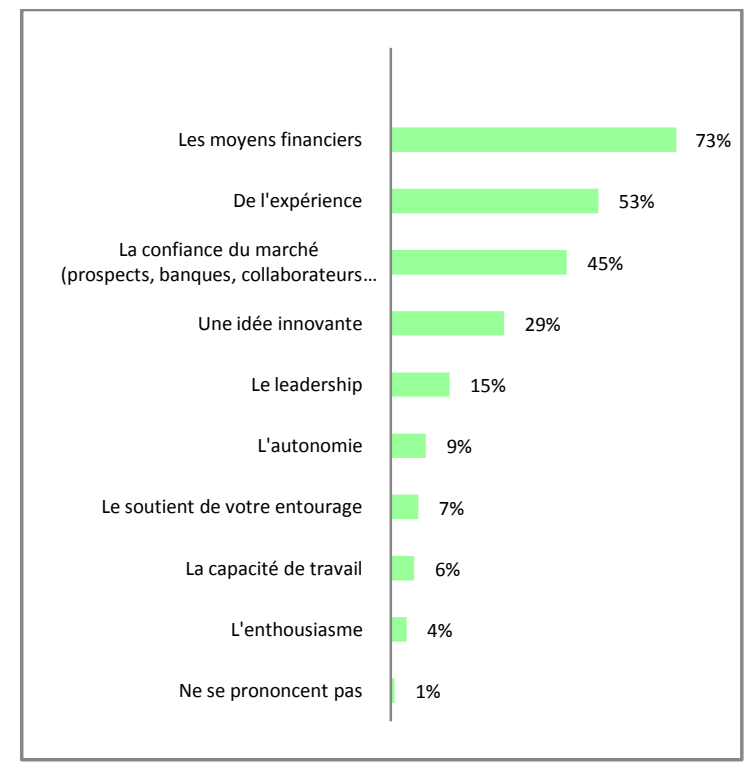

Figure. Main barriers for young people

Source: Survey Opinion way for MoovJee, entrepreneurship image to vocational high schools and students,

2015.

One of the ways to bridge this gap is to do an apprenticeship to develop their leadership skills. Collins (2005) Leadership 5-level course, going successively through each level to reach the highest level of management, is not necessary:

Level 5: company manager

Level 4: effective leader

Level 3: skilled manager

Level 2: active employee

Level 1: highly skilled individual

The study of different skill reference systems of sandwich course ${ }^{4}$ shows that this status helps develop in most cases level 1 and/or 2 leadership, or level 3 leadership in some cases. Thus, it would seem that apprentice-students develop leadership skills within Druker's meaning (2016), who defines the "real leader" common link through eight rules:

\footnotetext{
${ }^{4}$ Designed as part of the learning supervision of apprentice-students from University Apprenticeship Training Centre apprentices (CFA UNIV), Corsica.
} 
1. Ask yourself what needs to be done

2. Ask yourself what's good for the business

3. Develop action plans

4. Assume responsibility for decisions

5. Assume responsibility for communication

6. Focus on opportunities, not on issues

7. Conduct productive meetings

8. Think and use "We" instead of "I"

While a sandwich course system helps develop leadership, it also helps develop entrepreneurship. The table ${ }^{5}$ below lists all entrepreneurs graduates from the University through sandwich course programmes in the 6 months following completion of the course. To date, none of these entrepreneurial projects has been abandoned; this shows, at least intrinsically, a real managerial capacity of apprentice-students.

\begin{tabular}{|l|l|l|l|}
\hline Year & $\begin{array}{l}\text { Number of students } \\
\text { surveyed }\end{array}$ & $\begin{array}{l}\text { Number of businesses started } \\
\text { or taken over by students }\end{array}$ & $\begin{array}{l}\text { of which \# apprentice-students who } \\
\text { started/took over a business }\end{array}$ \\
\hline 2012 & 134 & 9 & 6 \\
\hline 2013 & 149 & 12 & 4 \\
\hline 2014 & 93 & 4 & 4 \\
\hline 2015 & 106 & 6 & 2 \\
\hline Average & 120.5 & 7.75 or $6.43 \%$ of students & $\begin{array}{l}4 \text { or } 51.6 \% \text { of young graduates entrepreneurs } \\
\text { completed a sandwich course }\end{array}$ \\
\hline
\end{tabular}

Apprentice-students represent on average $8 \%$ of students over the last 4 years, while they count for more than half of young entrepreneurs graduates.

It was found that half of businesses created/taken over by young graduates have been created/taken over by students who have completed a sandwich course. This reality is even more striking when we look specifically at students enrolled in a Bachelor of Professional Entrepreneurship (BPL) at the University of Corsica.

\begin{tabular}{|l|l|l|l|l|}
\hline & $\mathbf{2 0 1 1 - 2 0 1 2}$ & $\mathbf{2 0 1 2 - 2 0 1 3}$ & $\mathbf{2 0 1 3 - 2 0 1 4}$ & $\mathbf{2 0 1 4 - 2 0 1 5}$ \\
\hline Number of applications & 87 & 88 & 83 & 105 \\
\hline Number of students enrolled in the course & 22 & 23 & 25 & 21 \\
\hline Number of graduates & $95 \%$ & $87 \%$ & $100 \%$ & $100 \%$ \\
\hline Number of pedagogical enrollments in sandwich course & $9(40 \%)$ & $16(69.6 \%)$ & $17(68 \%)$ & $19(90 \%)$ \\
\hline $\begin{array}{l}\text { Number of students with the 'Entrepreneur Student' } \\
\text { status (created in 2014) }\end{array}$ & & & & 1 \\
\hline Number of new businesses identified & $3(13.6 \%)$ & $5(21.7 \%)$ & $4(16 \%)$ & $7(33 \%)$ \\
\hline
\end{tabular}

It was found that while students in entrepreneurship have become aware of the sandwich course challenges, the proportion of apprentice-students in LPE has more than doubled to reach $90 \%$ in 2015. At the same time, the proportion of new businesses/ businesses taken over by young people (graduates less than 6 months ago) increased from $13.6 \%$ to 33\%. Young people enrolled in this sandwich course develop more quickly their entrepreneurial skills, especially their leadership skills with corporate immersion, as they are in direct contact with entrepreneurs and entrepreneurial challenges to which they need to propose solutions.

Indeed, according to Shapero and Sokol (2005), the entrepreneurial intention results from two variables, the desirability and feasibility perceived:

\footnotetext{
${ }^{5}$ See Storai \& Rinieri (2016) for more details on this point CFA UNIV annually conducts 10 ministerial surveys on sandwich placement training system students (follow-up on employability in March $\mathrm{N}+1$, of outgoing students (graduates or not) through the sandwich course system).

${ }^{6}$ A pedagogically enrolled student is a student enrolled administratively and enrolled in a course module for the year. He is then considered pedagogically enrolled student for this course year.
} 
- Entrepreneurship desirability refers to individual value systems. It is built through the influence of culture, family, peers, and professional and education environments.

- Feasibility refers to accessing the necessary resources: financial, human and relational resources

The environment may be facilitator or inhibiting instead. Entrepreneurial behaviour is therefore intentional and start in the mind of the entrepreneur although not fully aware of it. The identity of the individual impacts the entrepreneurial intention. The characteristic elements of identity are not stable data, they change based on the experiences of the individual (Fisher 2015). Different mechanisms contribute to the identity change, including the identification concept which is to assess others referring to social and cultural models guiding behaviours and leading the entrepreneur to meet social demands; identity referents who are the individuals, specifically mark the image that we have on ourselves. For example, regular meetings with a company manager will change the entrepreneur. Considering entrepreneurial activities is therefore easier when identity referents lead the individual to demystify the Entrepreneur, including through discussions with company managers. Furthermore, the individual education and culture may encourage initiatives, creativity and the desire to entrepreneurial activities.

\section{FINDINGS}

It was found that the proportion of young people starting an entrepreneurial process is higher after a sandwich course and that the proportion of apprentice-students among young people choosing an entrepreneurship course, increases.

In the end, the benefits of the sandwich course policy based on entrepreneurship, can be grouped into two interlinked categories:

- Knowledge on entrepreneurship and 'Intrapreneurship': apprentice-students work with company managers during their apprenticeship period, these people are therefore trained to support a leader in expressing and implementing initiatives and in managing multiple (and interdisciplinary) involvements within the company.

- Initiative management: apprenticeship boosts entrepreneurial skills referring to anticipating (prospective logic), developing a strategic vision, creativity, as well as developing and specifying the strategy in the daily management (strategic management). By training independent human resources and giving them empirical knowledge of the business world, apprenticeship develops cognitive skills that help take initiatives and create a business.

Gaining those skills strengthens leadership and may lead young people to turn to entrepreneurial activities more quickly. This observation which should be sustained, logically boosts the path to building a knowledge economy adapted to the needs of the island territory. With the concurrent increase of qualification and employability of students generated by the development of the sandwich placement training system in higher education in general and at the University of Corsica in particular, structuring, creating and taking over businesses in Corsica are thoroughly consolidated. This trend, now well established in Corsica, is vital to the development of an ever-changing region.

Finally, besides the transfer of skills and intellectual stimulation from that specific training system, its purpose is to meet economic challenges with business development perspectives (business creation and takeover, internal development), but above all, to meet HR challenges by strengthening organisations. To this context, the empirical framework presented by Corsica, a small island economy, is most exemplary.

\section{REFERENCES}

COLLINS J., 2005, "Level 5 Leadership: The Triumph of Humility and Fierce Resolve", best of Harvard Business Review.

DRUCKER P., 2016, “Qu'est ce qu'un veritable manager?”, Harvard Business Review Hors série: Le must du leadership.

FISCHER G.N., 2015, Concepts fondamentaux de la psychologie sociale, ed. Dunod.

GILLET C., REYNET O., COADOUR D., 2015, « dispositif co-construit de formation au leadership, former au leadership réflexif au-delà de l'action », 2015, actes du 8e colloque Questions de Pédagogie dans l'Enseignement Supérieur. Innover: comment et pourquoi? 
KOTTER J.P., 1990, A force for change: How leadership differs from Management New York: free Press

LAPIERRE L., 2006, «Enseigner le leadership ou former vraiment des leaders? », Gestion, HEC Montreal, vol. 31

LAVIOLETTE E. 2011, «Leadership entrepreneurial : une analyse comparée du leadership et de l'entrepreneurship », in Leadership et Management, LAISÉ C., LEFEBVRE M.R., Denis CHRISTOL D. ed. De Boeck.

LEGER JARNIOU C., CERTOUX G., DEGEORGES J.M., LAMETA N., LEGOFF H., 2016, Entrepreneuriat, coll. Openbook, ed. Dunod.

OCDE, 2011, Panorama de l'Entrepreneuriat. Statistiques OECD Library.

SHAPERO, A. \& SOKOL, L., 1982, 'The Social Dimensions of Entrepreneurship', in C. Kent, D. Sexton, and K. H. Vesper (eds.) The Encyclopedia of Entrepreneurship. Englewood Cliffs, NJ: Prentice-Hall.

STORAÏ C.\& RINIERI L., 2016, "Regional human capital development policy and Sandwich placement trainingin higher education:lessons learned from the pioneering example of the

University of Corsica in a small island economy", Chinese Business Review, ISSN 1537-1514 May, Vol. 15, No. 5, 243-257.

\section{AUTHORS' BIOGRAPHY}

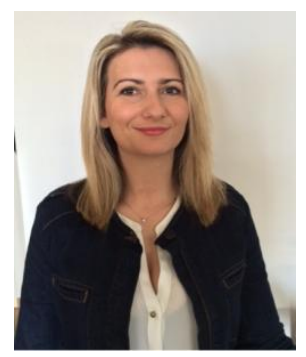

Nathalie LAMETA, is Teacher in Economy and Management, Educational Director of the Professional License Entrepreneurship at the University Institute of Technology Corsica.

She is member of the UMR LISA 6234 (mixed research unit) - University of Corsica. Her Researches focuses on Management and Entrepreneurial Strategy.

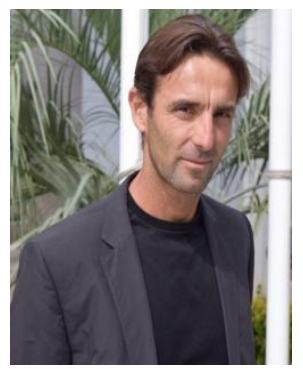

Christophe STORAÏ, is Lecturer in Economics and Director of the University Apprenticeship Training Centre (CFA UNIV) Corsica, University Institute of Technology Corsica.

He is member of UMR LISA 6234 (mixed research unit) - University of Corsica. His researches concern the domains of the territorial attractiveness, the location of the foreign direct investments and the valuation of the human resources. 